\title{
ANALISIS KELENGKAPAN IMUNISASI DASAR DI WILAYAH KERJA PUSKESMAS LEMO KABUPATEN BARITO UTARA
}

\section{ANALYSIS OF BASIC IMMUNIZATION IN THE WORKPLACE PUSKESMAS LEMO NORTH BARITO REGENCY}

\author{
Achmad Rizal $^{1)}$ dan Agus Jalpi ${ }^{1)}$ \\ ${ }^{I}$ Fakultas Kesehatan Masyarakat, Universitas Islam Kalimantan Muhammad Arsyad Al Banjari Banjarmasin \\ Email : achmadrizal.fkmuniska@gmail.com
}

\begin{abstract}
Healthy behaviour is a proactive attitude to maintain and improve health, prevent the risk of disease, protect yourself from disease threats and play an active role in public health movement activities. One of the healthy attitudes that must be created is the attitude of prevention and disease management with immunization activities. This research aims to analyse the relationship level of education, knowledge and attitude of baby mothers with the completeness of basic immunization in the work area of Puskesmas Lemo Teweh District of North Barito Regency. The method used is an analytical survey with a Cross Sectional approach aimed at knowing the relationship level of education, knowledge, attitude with immunization in the baby. The result is a relationship between knowledge and attitude with the completeness of immunization in infants, completeness of basic immunization in infants $48.4 \%$ ( 31 babies). To increase the percentage of completeness of basic immunization in Lemo Puskesmas is by improving the extension, especially about the benefits and schedule of immunization administration.
\end{abstract}

Keywords: Level of education, knowledge, behaviour, attitudes, completeness Immunization

\section{PENDAHULUAN}

Dalam visi pembangunan kesehatan Nasional yang menggambarkan masyarakat Indonesia di masa depan yang penduduknya hidup dalam lingkungan sehat. Dengan mengembangkan visi misi ini, maka masyarakat di harapkan mampu menjangkau pelayanan kesehatan yang bermutu, adil dan merata serta memiliki derajat kesehatan yang setinggi tingginya. Prilaku sehat adalah prilaku proaktif untuk memelihara dan meningkatkan kesehatan, mencegah resiko terjadinya penyakit, melindungi diri dari ancaman penyakit serta berperan aktif dalam kegiatan gerakan kesehatan masyarakat. Salah satu prilaku sehat yang harus di ciptakan adalah prilaku pencegahan dan penanggulangan penyakit dengan kegiatan imunisasi (DepKes, 2000).

Angka kesakitan bayi menjadi indikator kedua dalam menentukan derajat kesehatan anak, karena nilai kesakitan merupakan cerminan dari lemahnya daya tahan tubuh bayi dan anak balita. Angka kesakitan ini juga dapat dipengaruhi oleh status gizi, jaminan pelayanan kesehatan, layanan petugas kesehatan, perlindungan kesehatan anak, faktor sosial ekonomi dan pendidikan ibu. Penyebab kematian bayi di Indonesia adalah akibat berbagai penyakit yang sebenarnya dapat dicegah dengan imunisasi seperti tetanus, campak dan difteri. Hal ini terjadi karena masih kurangnya kesadaran masyarakat untuk memberi imunisasi pada anak (Azis, 2009).

Imunisasi atau kekebalan tubuh terhadap ancaman penyakit adalah tujuan utama dari pemberian vaksinasi. Pada hakekatnya kekebalan tubuh dapat dimiliki secara pasif maupun aktif. Keduanya dapat diperoleh secara alami maupun buatan (Ranuh, 2008). Oleh karena itu perlu dilakukan imunisasi sebagai upaya pencegahan terhadap serangan penyakit. Imunisasi telah terbukti sebagai salah satu upaya kesehatan masyarakat yang sangat penting. Program imunisasi telah 
menunjukkan keberhasilan yang luar biasa dan merupakan usaha yang sangat hemat biaya dalam mencegah penyakit menular (Kemenkes RI, 2003). Imunisasi juga telah berhasil menyelamatkan begitu banyak kehidupan dibandingkan dengan upaya kesehatan masyarakat lainnya.

Data Puskesmas Lemo Kabupaten Barito Utara Tahun 2017 persentase cakupan imunisasi lengkap tahun 2013 adalah 69,7\% target $80 \%$ dan tahun 2016 cakupan sebesar 72,5\% target $85 \%$, berarti selama 2 (dua) tahun berturut-turut Desa Lemo tidak UCI (Puskesmas Lemo, 2017). Dari pencapaian program imunisasi tersebut diatas dapat dikatakan masih adanya target yang belum tercapai, hal ini disebabkan oleh banyak sekali faktor penyebab, salah satunya adalah faktor yang berasal dari orang tua/ibu, bahwa ditemukan tingkat pendidikan orang tua, tingkat pengetahuan, sikap, umur ibu dan status pekerjaan berkaitan dengan status kelengkapan pemberian imunisasi anak.

Peran ibu pada program imunisasi sangat pentinglah penting di karenakan masih banyak ibu yang tidak mengerti manfaaat imunisasi itu sendiri. Walaupun imunisasi sudah diberikan gratis oleh pemerintah. Namun masih banyak anak yang belum mendapatkan imunisasi secara lengkap hal tersebut dikarenakan dengan berbagai alasan seperti pengetahuan ibu yang kurang tentang imunisasi dan rendahnya kesadaran ibu membawa anaknya ke Posyandu atau Puskesmas untuk mendapatkan imunisasi yang lengkap karena takut anaknya sakit setelah pemberian anak menjadi demam, dan ada pula yang merasa bahwa imunisasi tidak perlu untuk bayinya serta pendidikan ibu yang rendah. Berdasarkan latar belakang diatas maka tujuan dalam penelitian ini untuk menganalisis hubungan tingkat pendidikan, pengetahuan dan sikap ibu bayi dengan kelengkapan imunisasi dasar di wilayah kerja Puskesmas Lemo kecamatan Teweh Tengah kabupaten Barito Utara.

\section{METODE PENELITIAN}

Rancangan penelitian ini adalah penelitian survey analitik dengan pendekatan yang digunakan adalah cross-sectional penelitian yang dilakukan dengan mengambil waktu tertentu yang relatif pendek dan tempat tertentu. Responden dalam penelitian ini berjumlah 64 reeponden yaitu seluruh ibu yang mempunyai anak bayi berusia 12 sampai dengan 24 bulan. Variabel bebas adalah pendidikan, pengetahuan dan sikap ibu sedangkan variabel terikatnya adalah kelengkapan imunisasi dasar. Analisis data dilakukan secara manual dan komputerisasi dengan komputerisasi dengan uji statistik Chi square $\left(\mathrm{x}^{2}\right)$.

\section{HASIL DAN PEMBAHASAN}

Tabel 1 menunjukkan tidak ada hubungan antara tingkat pendidikan dengan kelegkapan imunisasi dasar pada bayi. Hal ini menunjukkan bahwa pendidikan tidak ada pengaruhnya terhadap imunisasi dasar pada bayi di wilayah kerja Puskesmas Lemo Kabupaten Barito Utara. Pendidikan terjadi melalui kegiatan atau proses belajar yang dapat terjadi dimana saja, kapan saja, dan oleh siapa saja. Kegiatan belajar mempunyai ciri-ciri: belajar adalah kegiatan yang menghasilkan perubahan pada diri individu, kelompok, atau masyarakat yang sedang belajar, baik aktual maupun potensial (Notoadmodjo, 2007). Dari hasil penelitian menunjukan bahwa pendidikan tidak menjamin tingginya pengetahuan seseorang untuk memberikan imunisasi dasar pada bayinya. Hasil penelitian didapatkan ibu yang berpendidikan SMA lah yang jarang mengimunisasikan bayinya dikarenakan pengetahuan ibu yang sangat minim tentang manfaat dari imunisasi. Hal ini juga pernah dikemukakan oleh effendi (2009) bahwa seorang yang berpendidikan rendah tidak berarti mutlak berpengetahuan rendah pula. Peningkatan pengetahuan tidak mutlak diperoleh di pendidikan formal, akan tetapi juga dapat diperoleh pada pendidikan non formal.

Tabel 2 menunjukkan ada hubungan bermakna antara tingkat pengetahuan ibu dengan kelengkapan imunisasi dasar pada bayi. Hasil penelitian mengemukaan bahwa Pengetahuan adalah keseluruhan pemikiran, gagasan, ide, konsep dan pemahaman yang dimiliki manusia tentang dunia dan segala isinya termasuk manusia dan kehidupan. Pengetahuan merupakan penalaran, penjelasan dan pemahaman manusia tentang segala sesuatu, juga mencakup praktek atau kemampuan teknis dalam memecahkan berbagai persoalan hidup yang belum dibuktikan secara sistimatis sesuai dengan penelitian Slamet (2003). 
Tabel 1. Analisis tingkat pendidikan dengan kelengkapan imunisasi dasar pada bayi di wilayah kerja Puskesmas Lemo Kabupaten Barito Utara

\begin{tabular}{|c|c|c|c|c|c|c|c|}
\hline \multirow{3}{*}{ Tingkat pendidikan } & \multicolumn{4}{|c|}{ Kelengkapan Imunisasi } & \multirow{2}{*}{\multicolumn{2}{|c|}{ Total }} & \multirow{3}{*}{$\begin{array}{l}\text { Value } \\
\text { (p) }\end{array}$} \\
\hline & \multicolumn{2}{|c|}{ Lengkap } & \multicolumn{2}{|c|}{ Tidak Lengkap } & & & \\
\hline & Jumlah & $\%$ & Jumlah & $\%$ & Jumlah & $\%$ & \\
\hline SD & 3 & 27,3 & 8 & 72,7 & 11 & 100 & \\
\hline SLTP & 10 & 47,6 & 11 & 52,4 & 21 & 100 & 0,251 \\
\hline SMA & 14 & 51,9 & 13 & 48,1 & 27 & 100 & \\
\hline Diploma/ Sarjana & 4 & 80 & 1 & 20 & 5 & 100 & \\
\hline Total & 31 & 48,4 & 33 & 51,6 & 64 & 100 & \\
\hline
\end{tabular}

Tabel 2. Analisis Tingkat Pengetahuan Ibu Dengan Kelengkapan Imunisasi Dasar pada Bayi di wilayah kerja Puskesmas Lemo Kabupaten Barito Utara

\begin{tabular}{|c|c|c|c|c|c|c|c|}
\hline \multirow{3}{*}{ Pengetahuan } & \multicolumn{4}{|c|}{ Kelengkapan Imunisasi } & \multirow{2}{*}{\multicolumn{2}{|c|}{ Total }} & \multirow{3}{*}{ Value $(\mathrm{p})$} \\
\hline & \multicolumn{2}{|c|}{ Lengkap } & \multicolumn{2}{|c|}{ Tidak Lengkap } & & & \\
\hline & Jumlah & $\%$ & Jumlah & $\%$ & Jumlah & $\%$ & \\
\hline Baik & 29 & 96,7 & 1 & 3,3 & 30 & 100 & \\
\hline Cukup & 2 & 8,3 & 22 & 91,7 & 24 & 100 & \\
\hline Kurang & 0 & 0 & 10 & 100 & 10 & 100 & 0,000 \\
\hline Total & 31 & 48,4 & 33 & 51,6 & 64 & 100 & \\
\hline
\end{tabular}

Peneliti mengemukakan adanya hasil yang bermakna antara tingkat pengetahuan responden dengan kelengkapan imunisasi pada bayi di wilayah kerja Puskesmas Lemo Kabupaten Barito Utara. Hal

Tabel 3 menunjukkan adanya hubungan bermakna antara sikap dengan kelengkapan imunisasi dasar pada bayi karena nilai signifikan $\mathrm{P}=$ 0,000 lebih kecil dari $\alpha=0,1$. Sesuai dengan teori yang di kemukakan oleh Risnawati (2014), sikap merupakan suatu bentuk atau reaksi perasaan seseorang terhadap suatu objek. Sikap atau respon positif dari orang tua dalam mengimunisasikan bayinya akan mendukung atau memiliki pengaruh pada pertumbuhan anak. Dengan sikap yang baik maka akan membuat orang tua mengerti tentang pentingnya imunisasi bagi bayinya. Sikap yang baik juga akan berdampak pada kelengkapan imunisasi yang di terima oleh seorang anak. Maka dapat disimpulkan ada Analisis teori dengan hasil penelitian. ini terjadi disebabkan dengan pengetahuan yang baik tentang imunisasi, kegunaan imunisasi maka ibu akan berusaha untuk memberikan imunisasi karena tanpa imunisasi anak akan rentan terhadap penyakit.

Peneliti mengemukakan bahwa dengan adanya sikap yang baik maka akan timbul respon ibu dalam pemilihan pola hidup sehat terhadap anak-anaknya khususnaya tentang pemberian imuisasi, sehingga dengan sikap yang baik tersebut dapat meningkatkan derajat kesehatan bayi dan anak.

\section{KESIMPULAN}

Berdasarkan hasil penelitian dan pembahasan mengenai Analisis kelengkapan imunisasi dasar di wilayah kerja puskesmas lemo kabupaten barito utara tahun 2016 maka dapat diperoleh kesimpulan yaitu ada hubungan antara pengetahuan dengan kelengkapan imunisasi dasar dan ada hubungan antara sikap Ibu dengan dengan kelengkapan imunisasi. 
Tabel 3. Analisis Sikap Ibu Dengan Kelengkapan Imunisasi Dasar pada Bayi di wilayah kerja Puskesmas Lemo Kabupaten Barito Utara

\begin{tabular}{ccccccccc}
\hline \multirow{2}{*}{ Sikap } & \multicolumn{3}{c}{ Kelengkapan Imunisasi } & \multicolumn{3}{c}{ Total } & \multirow{2}{*}{ Value (p) } \\
\cline { 2 - 6 } & \multicolumn{2}{c}{ Lengkap } & \multicolumn{3}{c}{ Tidak Lengkap } & & \\
Jumlah & $\%$ & Jumlah & $\%$ & & Jumlah & $\%$ & \\
Sangat Baik & 5 & 100 & 0 & 0 & 5 & 100 & \\
Baik & 24 & 70,6 & 10 & 29,4 & 34 & 100 & 0,000 \\
Tidak Baik & 2 & 8,7 & 21 & 91,3 & 23 & 100 & \\
Sangat Tidak Baik & 0 & 0 & 2 & 100 & 2 & 100 & \\
Total & 31 & 48,4 & 33 & 51,6 & 64 & 100 & \\
\hline
\end{tabular}

\section{DAFTAR PUSTAKA}

Depkes RI, 2000. Pedoman Operasional Pelayanan Imunisasi. Jakarta.

Effendi , Ferry dan Makhfudli, 2009. Keperawatan kesehatan komunitas. Jakarta : Salemba Medika.

Notoatmodjo, S, 2007. Promosi Kesehatan dan Ilmu Perilaku. Jakarta: Rineka Cipta.

Puskesmas Lemo, 2017. Data Laporan Puskesmas Lemo Kabupaten Barito Utara. Barito Utara, Muara Teweh.

Ranuh, I.G.N. 2008. Pedoman Iminusasi di Indonesia. Cetakan ketiga. Jakarta: IDAI

Risnawati, D., 2014. Pengaruh Pengetahuan, Pendidikan, Pendapatan, dan Budaya Ibu Terhadap Kelengkapan Imunisasi Dasar Lengkap di Kelurahan Pacarkembang. Skripsi. Fakultas Kedokteran Universitas Airlangga Surabaya.

Slamet, 2003, Belajar dan Faktor-Faktor yang Mempengaruhinya, Cetakan keempat. Jakarta: Rieneka Cipta. 